\title{
中国恵州西湖の景観形成特徵と杭州西湖景観が 及ぼした影響
}

\section{A Study on Landscape Forming of Hui- Zhou West Lake in China and on Influence of Landscape Hang- Zhou West Lake}

\author{
沈 悦* 熊谷洋一* 下村彰男 ${ }^{*}$ 小野良平*
}

Yue SHEN Yoichi KUMAGAI Akio SHIMOMURA Ryohei ONO

摘要 : 本研究は, 中国広東省恵州西湖の景観形成の特徽及び杭州西湖量観が及ぼした影響について考

察することを目的とした。研究の方法は，関連する歴史資料や詩集図絵などの文献を調查し，その景

観整備過程を辿りながら，地形図及び現地調查による視覚分析を行った。その分析結果と杭州西湖の

景観構成との比較分析を通して考察を進めた。その結果, 恵州西湖の景観形成の特徵として, 以下が あげられた。1)杭州西湖景観の影響を受けつつも，立地条件に合わせた独自の景観形成を行った。2） 視点操作を主体に長い年月をかけて景観形成を行った。3)杭州西湖景観形成手法に類似しているもの

の, 名景化手法に特徵がある。

\section{1. 研究の目的と方法}

中国広東省の恵州西湖は, 中国及び日本の造園に影響を与えた 杭州西湖風景地之同様に, 数百年にわたる景観に配慮した人工改 造の歴史を有している。また, 杭州西湖の景観形成に大きく貢献 した蘇東坡が恵州西湖の景観づくりに参与したことにより, 恵州 西湖の景観も多くの人々に知られることになった。恵州西湖誌に は「夫中国西湖三十六，唯恵州足並杭州（中国には 36 筒所の西 湖があり, そのうち杭州西湖之並べられるのは恵州西湖だけであ る)」と記されている”。しかし近代以降, 戦争, 災害, また風 景への配慮不足などの諸原因から, 恵州西湖景観は荒廃が進み, 忘れ去られて研究む進んでいない。本研究は中国名風景地の再整 備の契機とするべく, 杭州西湖の景観形成などの既存研究2)3314 を 踏まえた上で, 恵州西湖を対象とし, その景観形成の流れを辿り ながら景観形成の特徴, 主要な手法を明らかにするとともに, 杭 州西湖の景観形成が及ぼした影響について考察することを目的と した。

方法としては関連する歴史文献, 困絵, 詩集などを収集し分析 するとともに, 現地調查及びヒアリングによる補完を行い, 恵州 西湖の沿革, 立地条件及び景観上の形成経緯および杭州西湖之の 関連などを全般的に把握した。さらに地形网を基に恵州西湖周辺 の主要な視点からの視覚分析を行い, その結果を杭州西湖の景観 構成と比較し，その景観上の類似点・相違点を明確にした。そし て杭州西湖の景観形成手法加の影響を考察するともに, 恵州西 湖における景観づくりの考え方について検討した。

定量的に視覚分析を進める上で, 恵州西湖周辺において, 主要 な視点と視対象を抽出し, 数值地形モデル（DTM）を作成して, 視対象の可視性, 視距離, 高低差, 視角 (仰角, 俯角) の検討を 行った。また構造物について, その分布や主要視点からの視距離 の検討を通じて, 構造物と他の景観構成要素の関係, 配置を把握 した。さらに塔のような大規模の構造物については, その構造物 と他の要素（特に地形）との関係を定量的に検討し，杭州西湖之 関連する名景について，DTM でパースを描いて検討を行った。 そして, これらの視覚分析の検討にあたっては, 同様の条件で分 析した杭州西湖の視覚分析結果との比較検討を行った。

これらの作業は主に広東省国土广・湖北省測絵局が 1994 年に 測量した五千分の一地形図を用い, 各文献上の古い地図・図

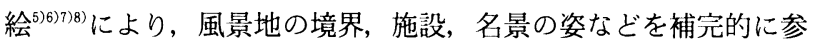

照した。画像的情報に関しては 1995 年の現地調査（風景地範井, 地形・水系, 各時代の諸施設の確認, 地方管理部門のヒヤリング 等）の写真の他, 過去の写真などの風景区資料 ${ }^{97}$ から抽出し, 現 況との比較・確認を行い, 補足的に参照した。

\section{2. 恵州西湖の景観構成の特徵}

\section{(1) 恵州西湖の景観構成分析}

恵州西湖は広東省恵州市（経度 $140^{\circ} 17^{\prime}$ ，緯度 $23^{\circ} 3^{\prime}$ ）に属 し, 恵州市街地の西に隣接する湖である。歴史の過程で, 湖岸が 埋め立てられたり，湖面上に多数の堤や橋などが造られたが，そ れによって現在の西湖は五つの小湖により構成される姿となった (南湖, 平湖, 豊湖, 䱐湖, 菱湖と呼ばれる)。これらの各小湖が それぞれに山と重なり合って，狭長で複雑な地形が恵州西湖景観 の一つの特徴となっている（図一-1）。

この恵州西湖景観は，杭州西湖之類似した雲网気を有すると言 われてきた。清時代（18世紀）の李仲昭が恵州西湖景観に関し て「画巻西卮繞旧遊, 此身疑尚在杭州（微風を当たりながら画の 如く風景の中で遊覧し回って，自分の身がまだ杭州にいると疑う

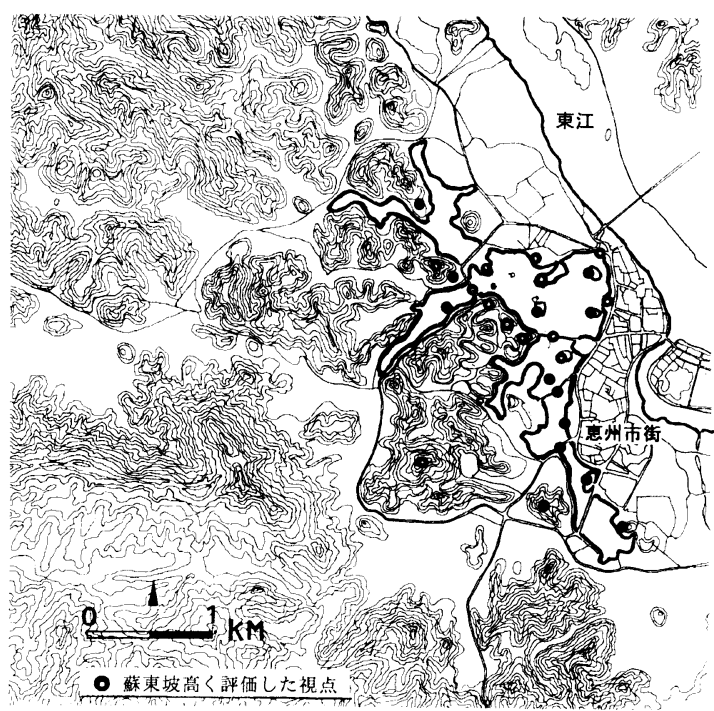

図一１＼cjkstart恵州西湖周辺の地形及び抽出した視点分布図 


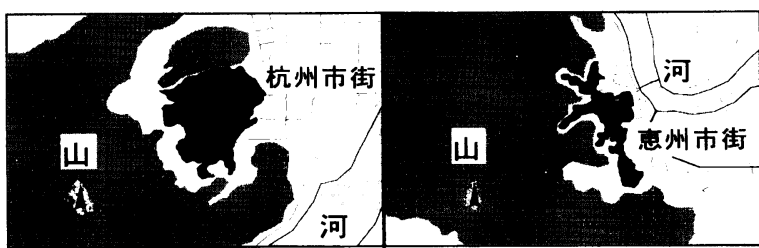

図-2 恵州西湖と杭州西湖の平面比較図

のだ)」と詠じたいわれる詩文がその一つである ${ }^{10)}$ 。恵州西湖は 网一2のように, 湖を中心として, 三方を山に囲まれ, 東側に恵 州市街が展開してきた。これは杭州西湖の「三方山一方城」と同 様の空間構成である。また恵州市及び杭州市の市街地の位置を比 較すると，二箇所とも同じように西部の湖（西湖）と東部の大河 （恵州の東江あるいは杭州の銭唐江）に挟まれた位置関係となっ ており，立地条件の類似性を見ることができる。

しかしながら恵州西湖の形状は, 狭長で分散しており, さらに 曲折した形を呈しているため, 大部分の視点からは全体を見通す ことができない。したがってこぢんまりとまとまった景観となっ ており，その点で杭州西湖と異なっている。近代の美術家は「西 湖各有妙, 此以曲折勝（各西湖は各々素晴らしい所を有しており, ここは曲折の景が最高だ)」と評価した ${ }^{11)} 。$

\section{(2) 視覚分析}

次に恵州西湖の見えについて視覚分析を行った。現代の地形情 報をべースにして, 歴史上の名景, 名拠点及び現代観光動線上の 拠点 26 筒所を視点として抽出し（図－1）分析を行った。

各山頂（視点が 7 筒所）から湖を見ると, 図一 3 のように, 手 前の岸は俯角 $10^{\circ}$ 前後で, 対岸の湖岸線は $1^{\circ} \sim 2^{\circ}$ で見るこ とができる。これは樋口の俯瞰景観に関する知見 ${ }^{22)}$ を参照する と, 恵州西湖の眺望が主題として確保された上, 湖面の開放感も 感じられる景観であることがわかる。一方, 湖中の島や湖岸など に存在する平地の視点（19 簓所）から湖周辺の山々を見る場合,

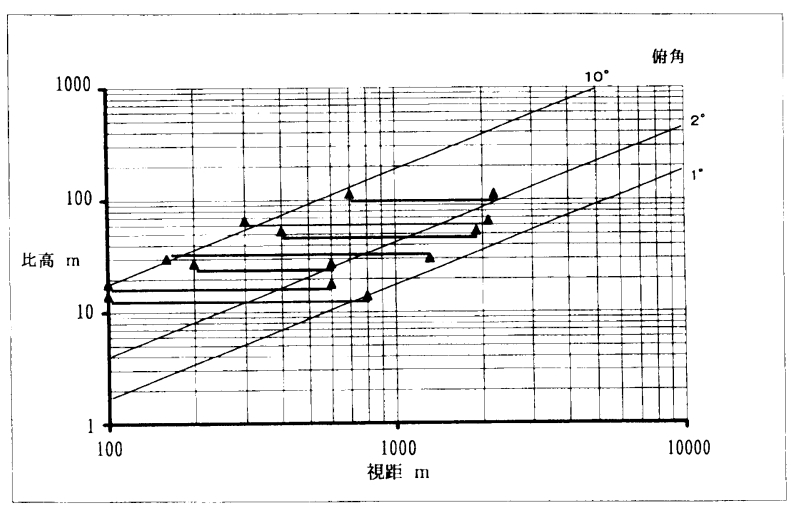

図ー3 山頂など高視点から湖の見え方（恵州）

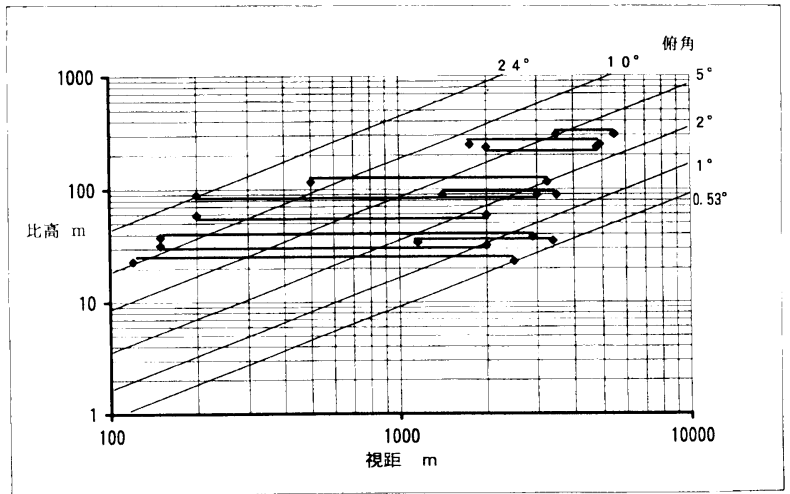

図ー4 山頂など高視点から湖の見え方（杭州）

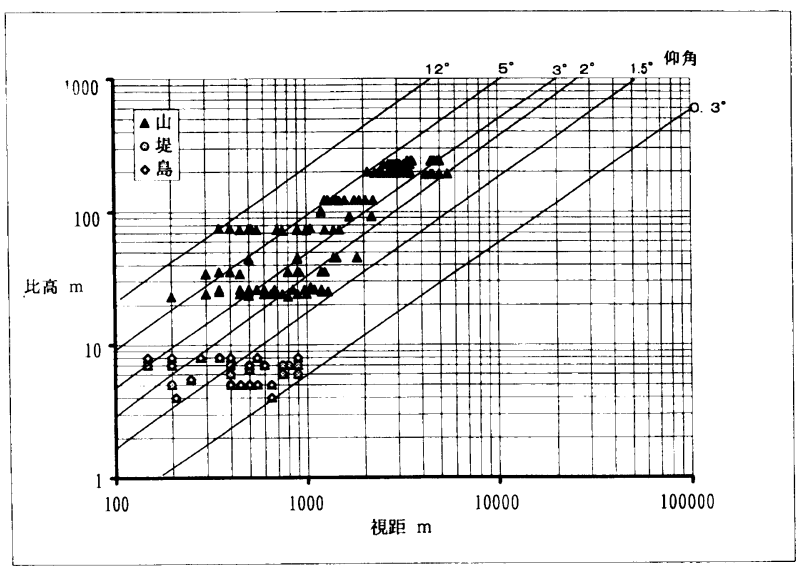

図-5 平地の視点から恵州西湖周辺の山の見え方

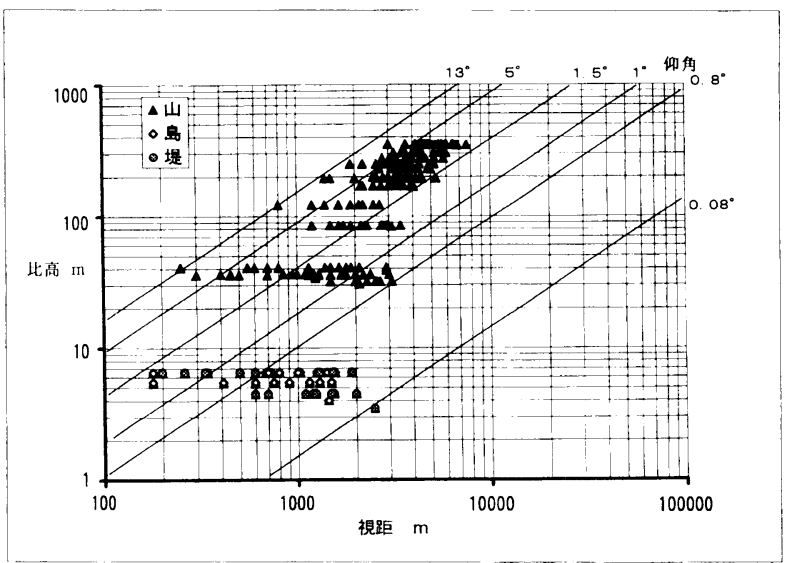

図-6 平地の視点から杭州西湖周辺の山の見え方

仰角は $5^{\circ}$ 以下の数值が多く（図- 5 ), 囲まれ感の弱い「平遠 の景観」 ${ }^{13)}$ と言える。これらの結果を杭州西湖のデー夕（図 4, 6 ）と比較すると, 次の結果が得られる

(1)類似点: 恵州西湖の湖面は杭州西湖の湖面より狭いが, 視点 から湖面までの比高が杭州西湖より小さいため（恵州の場合，比 高が $15 \mathrm{~m} \sim 100 \mathrm{~m}$ の範囲であるのに対し，杭州の場合は，比高が 概ね $25 \mathrm{~m} \sim 300 \mathrm{~m}$ の範井), 俯角及び仰角の数值は類似している。 また周辺の山に対する仰角も類似した数值を示しており，長い年 月をかけて選択形成された視点が, 結果的に杭州西湖と同質の景 観体験を支えるものであったと言える。

(2)相違点 : 俯角の数值がより狭い範囲に偏っており, 杭州西湖 よりも広がり感に欠ける。恵州西湖による平地視点の場合は, 堤 や島などの要素と山の組み合わせに首状の構成が見られるものの, 杭州西湖景観構成の重要な特徵である洗練された三層構造の景観 を形成しておらず, 散漫化に宿っている。また, 近距離に存在す る低山の仰角が高く, 遠視距の高山と交互にスカイラインを形成 しており，より多様な景観が見られる点も指摘できる。これは湖 が狭長かつ曲折していることが大きく影響していると言える。

そして, このような恵州西湖の自然風景の中に, 過去の整備を 通して人文景観が充実してきた。恵州西湖は杭州西湖に比べ堤の 数が多く, また, 小規模構造物（寺, 小庭園, 橋, 閣, 楼, 亭な ど）湖中の島，堤上，水辺，山中に数多く存在した（図-7）。 規模が大きく注目される塔は, 湖に接している低山山頂に位置し ていた。図ー8は現代のデー夕に基づいて塔と山水の組合せを示 している。この図を検討すると, 塔が仰角にして $1.5^{\circ} \sim 10$ 数度 の範囲で見られ，景観全体の中で大きく注目されることがわかる。 


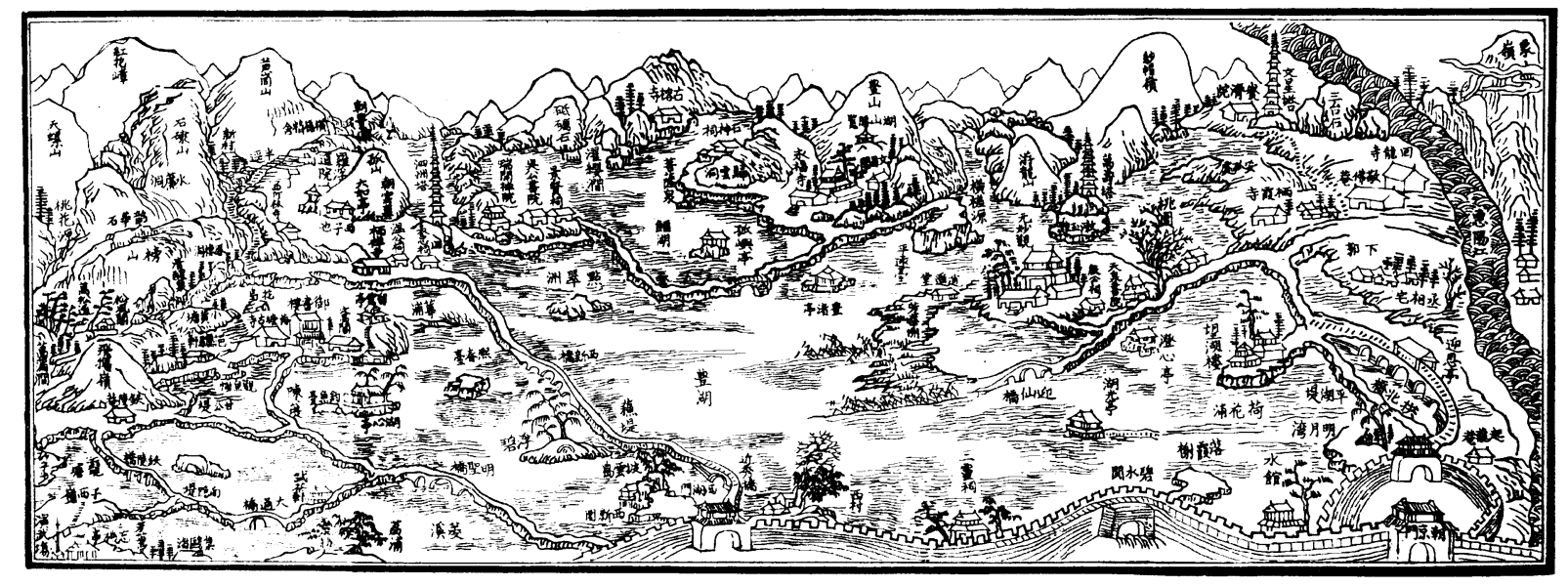

図-7 清時代の恵州西湖風景全図 ${ }^{8)}$

\section{（3）恵州西湖の景観構成の特徵}

以上の分析をまとめると, 恵州西湖の景観構成の特徴として次 のような結果が得られる。

(1)杭州西湖と同様, 湖を中心とし, 「三力山一方城」といった 三方を囲まれ，一方開放された空間構成となっている。

(2)狭長・曲折の湖面形状のため,こじんまりとまとまっている ものの広がり感が薄い景観を呈している。

(3)杭州西湖のような洗練された三層構造を欠いている。一方, 狭長で曲折した湖周辺に視点が分布し，見通しを欠くものの，よ り多様・豊富な景観が見られる。

(4)人文景観が数多く存在し, 重要な役割を果たしている。

\section{3. 恵州西湖の景観形成}

\section{（1）恵州西湖景観の変遷}

恵州西湖の湖・山は地質学上の中生代第三紀に，地款変動によっ て生成された。東晋時代 (4 世紀)には, 湖周辺の最初の拠点 として「興龍寺」が建立された。この「興龍寺」は唐の時代（7 世紀）に「開元寺」と改称され，当時の名勝として「恵州風景」 の初めての記載となった ${ }^{(4)}$ 。同時代には湖の周辺に永福寺, 泗洲 寺, 無量寿院など, 寺が次々之建立され, 湖周辺の遊覧拠点が徐々 に増えていった。また，湖畔の低山の山頂に大規模な構造物であ る泗洲塔が建てられ，自然の川水に人文的な添景が与えられた。

宋の時代（11 世紀）になると, 恵州西湖の水利整備を目的とし て西湖に大規模な人工改造が行われた。まず地方官（領州）の陳 称により, 農業用の灌溉と湖を東西に横断する交通動線確保のた め堤が造成された。この堤は湖の水位のコントロールにも使われ た。紹聖年初 (1094 1097 年), 杭州西湖の景観形成に貢献した 著名な文人・画家の蘇東坡が恵州地方官になり，在任の三年間に

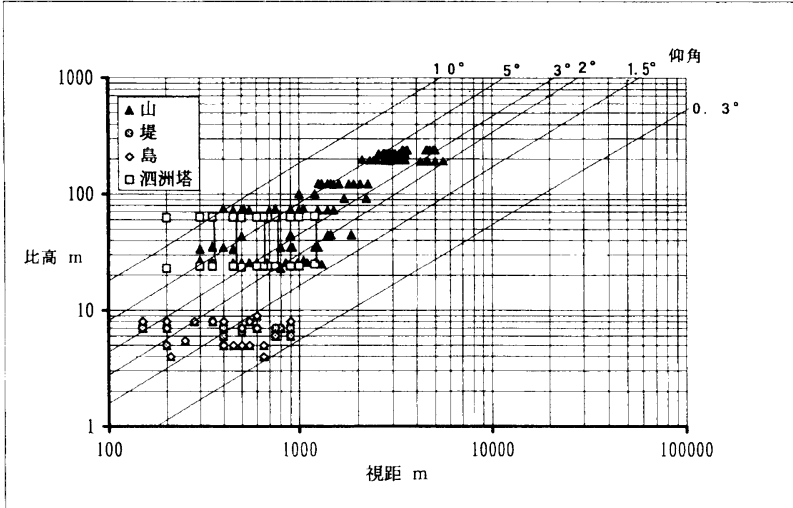

図-8 恵州西湖の視対象と重要構造物の見え方
恵州西湖の整備に腕をふるった。交通動線など諸問題を解決する べく永福寺の傍らに杭州西湖の「白堤」に似た「煙霞堤 ${ }^{15)}$ ， そ して湖中央の東西両岸の間に長堤（蘇堤）及び橋 (西新橋) を造つ た。さらにその橋の近傍に楼を建てて「壮其勢於上（堤に添景を 加える) $\rfloor^{16)}$ とともに，堤上には杭州西湖と同様に柳などの植栽 により修景を行った。後世の「西新橋記」には,「湖の西側へは, 樵漁業者と寺などへの遊覧の人だけが行っていた。一本の蔁を渡 しただけでも渡れる程度の近さなのに，なぜ堤・橋が造られたの か, やはり湖・山の素晴らしさを引き出すこと, 高い所まで登れ, 山水が眺望できるためだ。それによって，恵州の偉観が成立した のであろう」と記されているという ${ }^{17)}$ 。修景上の意図的な整備で あることを示す確証は得られないものの, 優れた造景性から，そ の意図を読み取ることは容易である。また，蘇東坡は景観的な整 備だけではなく, 湖の周辺を巡り, 風景を詠った詩文を残してお り, 恵州西湖景観の素晴らしさを伝え, 当時の湖の風景地である 杭州, 穎州と同じ「名湖」のレベルに恵州西湖を到達させる上で 大きく貢献した ${ }^{18)}$ 。恵州西湖が名風景地として確立したのはこの 時期だったが，蘇氏の詩による「玉塔微闌」の景観は恵州西湖の 代表景として時代变化に影響されず現在に伝わっている。

明, 清の時代になると, 都市の拡大によって惠州西湖の南北が 大きく開発され, 土地利用む拡大して湖周辺に多くの堤, 小橋, 塔などが整備された。景観の観賞拠点や視対象の増加によって, 景観も多様性を増し, 恵州西湖の八景, 十四景が選定されたこと は当時の文献に記れているという ${ }^{199}$ 。民国時代（1919～1949） になってからは, 戦争のために山や丘が破壊されたり, 交通量の 増加により道路の整備や堤の拡幅が行われて, 湖水面が縮小され ることとなり，大規模構造物である塔が一つを残して破壊された。 従来の恵州西湖の景観のスケール感が損なわれる事態となったこ とが推定される。1949 年以降, 新政府が都市の復興事業をし始め, 湖周辺の道路整備や古い文化財の修復, 名拠点への亭, 小橋, 記 念館等の付加など ${ }^{0)}$, 西湖景観の再整備が徐々に進んでいる。

恵州西湖景観は歴代の整備を経てきたもので，それに関わる人 物は著名な蘇氏の他に, 唐時代の僧伽, 宋時代王象之, 明時代祝 允明, 甘公亮, 清時代呉騫等百余りの文人・地方官たちが西湖景 観形成に貢献したことが文献にも記されている21)。

(2) 景観形成手法

(i ) 視点および視対象の操作

蘇氏は恵州に在任中の 3 年間に, 長堤や島, 小構造物を整備し, 湖面の分割や視点視対象づくりなど, 恵州西湖景観の形成に大き く貢献した他, 湖の周辺を視察, 遊覧し, 優れた景観について詩 文などを残した。以下はその記載をもとに, 蘇東坡の高く評価し た視点（山頂など高視点）からの視覚分析結果である。図ー9は 


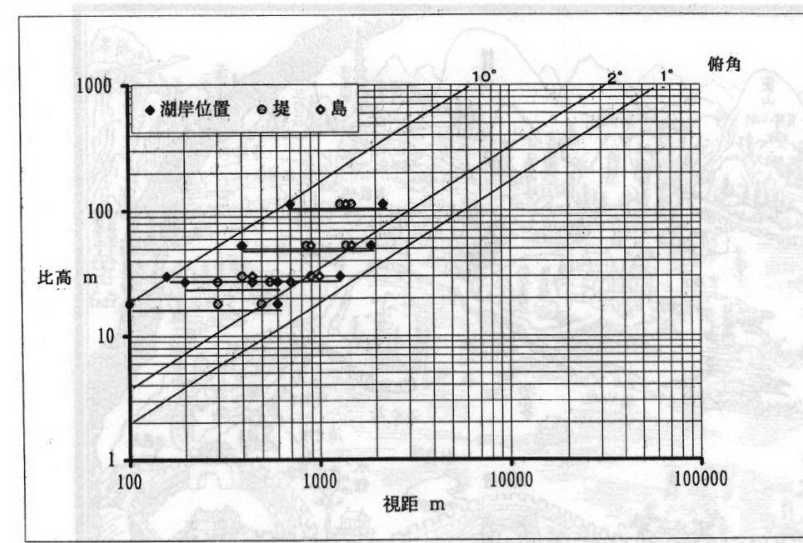

図-9 山頂等高視点から湖中の島・堤の見え方 （蘇東坡高く評価した視点）

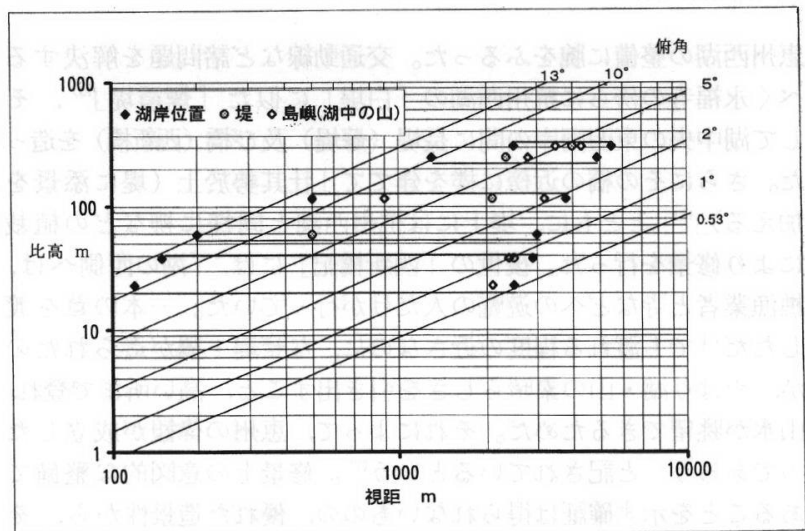

図－10 宋時代における杭州西湖周辺の山頂から湖中の堤の見え方

蘇氏によって整備が行われた後の恵州西湖において, 周辺の山頂 から湖中の島や堤を俯瞰した分析図である。杭州西湖（図－10） と比較して, 湖中の視対象の数が多いことがわかる。その他恵州 西湖の地形的特徴を考元合わせると以下の点が考察される。 (1)堤の造成によって狭長で曲折した湖面が区分され, 複数の水域 が形成された。それによって景観の分節感と奥行感が増強された。 (2)また堤は, 各水域に整備された島とともに, 加えられた風景要 素として, 新たな視対象となっており, 豊かな水景を演出するこ とにも貢献した。

図-11 は蘇氏が高く評価した場所を視点（湖中の島, 堤, 湖畔 の拠点など平地に位置している視点）とした場合の視覚分析図で ある。湖中の島・堤を見た場合，視距が $0.35 \sim 0.9 \mathrm{~km}$ で，仰角は

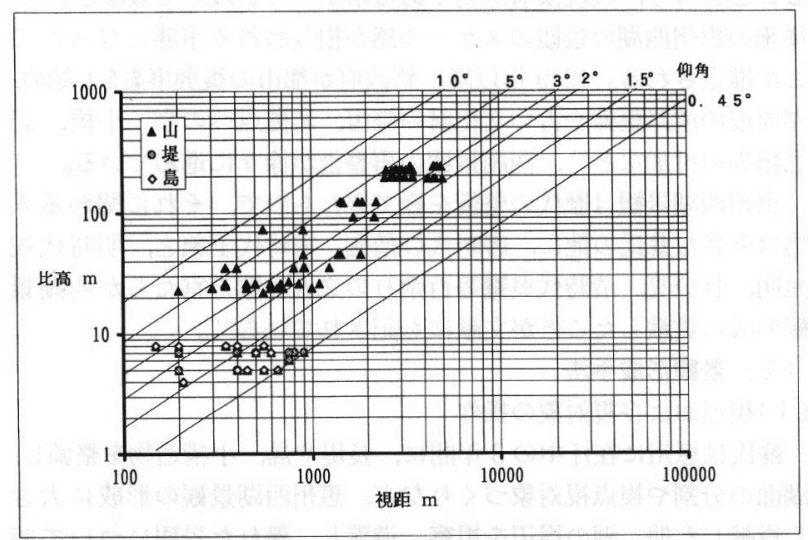

図-11 平地の視点から各視対象の見え方 (恵州) （蘇東坡高く評価した視点）

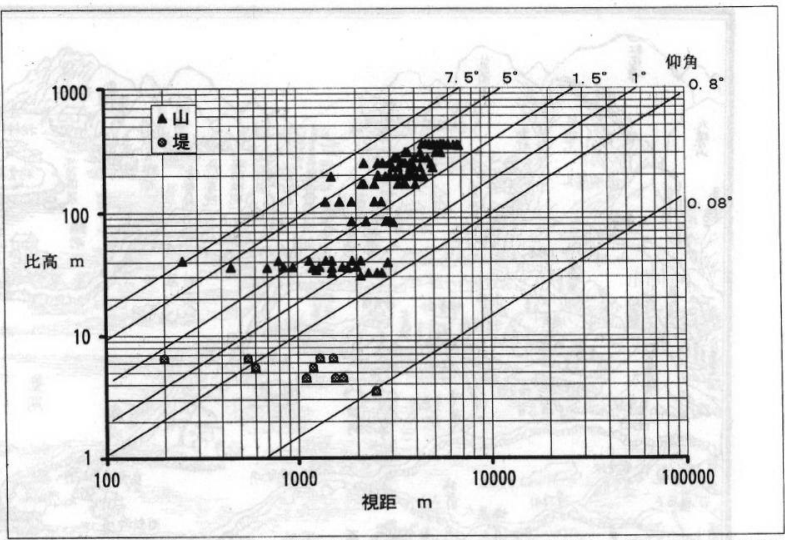

図ー12 宋時代における平地の視点から各視対象の見え方（杭州）

$0.45^{\circ} \sim 1.7^{\circ}$ の範囲が多いことがわかる。また湖畔に位置してい る低山を見る場合, 視距の $0.45 \sim 2 \mathrm{~km}$, また仰角 $1.7^{\circ} \sim 4^{\circ}$ の 範囲である。更に, 湖から離れている標高の高い山を見る場合, 視距が $1.5 \sim 5 \mathrm{~km}$, 仰角が $2^{\circ} \sim 5^{\circ}$ の範囲で多く見られること がわかった。このように堤や島は, 水景に変化をもたらしただけ ではなく，景観の第一層を形成した。

また，これを同時代 (宋) の杭州西湖のデー夕（図-12）及び 湖周辺の平地視点全体から見たデータ（図ー5）と比較すると， 蘇氏が選んだ視点から見た恵州西湖の景観は, 宋時代の杭州西湖 景観のように洗練された三層構造を呈してはいないあのの, 恵州 西湖周辺の平地視点全体からの景観に比べると, 三層構造の特徴 がより鮮明になっていることがわかった（写真－1）。これら蘇 氏が抽出した視点を検討する, と, 大部分が湖の中心部 (平湖, 豊 湖）に位置していたことがわかる。宋時代以降, 施設の整備が南

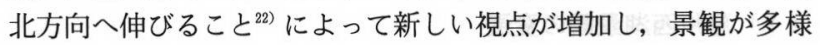
化して散漫化が進んだと考えられる。

\section{(ii)人文景観の整備}

一方, 構造物に関しては, 高さ 30 数 $\mathrm{m}$ 及ぶ塔が視覚的に目立 つあのであった。湖の中心部西岸の西山（湖畔の低山）山頂に建 てられた泗洲塔は, その塔と山水に構成された景観の美しさが蘇 東坡の詩に詠われ, 著名な「玉塔微瀾 (雁塔斜暉)」という名景 が形成された。これは杭州西湖十景の「雷峰夕照」に類似してい

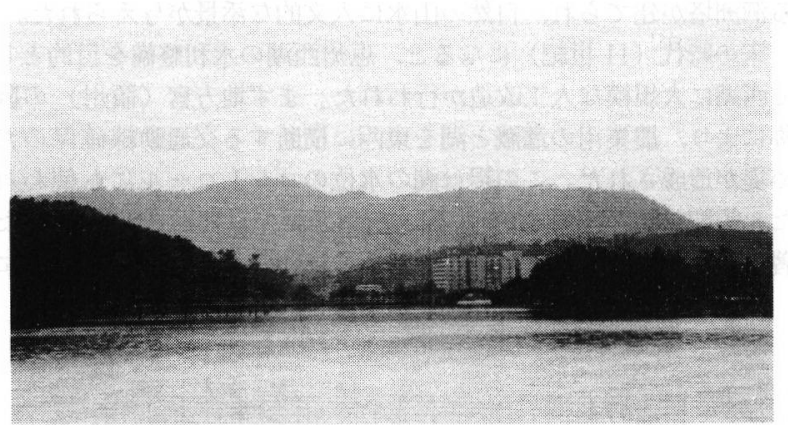

写真-1 元妙観前から煙霞堤方向を望む

ると評判になったあのである。図一13 は蘇氏時期（宋時代）に平 地の各視点から見た泗洲塔と山水の組み合わせが形成した景観の 視覚分析結果である(地形デー夕は現代のもの)。泗洲塔は層構 造の二層目に位置しており, 仰角は $4^{\circ} \sim 10$ 数度で, 目に入りや すく, 立地した二層目の山を強調する役割を果たすとともに, 風 景に注視点を与え, 添景として景観を引き締めしていたことがわ かる (写真 -2$)$ 。同時代の杭州西湖のデー夕(図-14) と比較する 之, 景観構成上の類似性が確認できる。この「玉塔微瀾」の景観 は, 蘇東坡により定着させられ, 年月を経て現在でも恵州景観の 


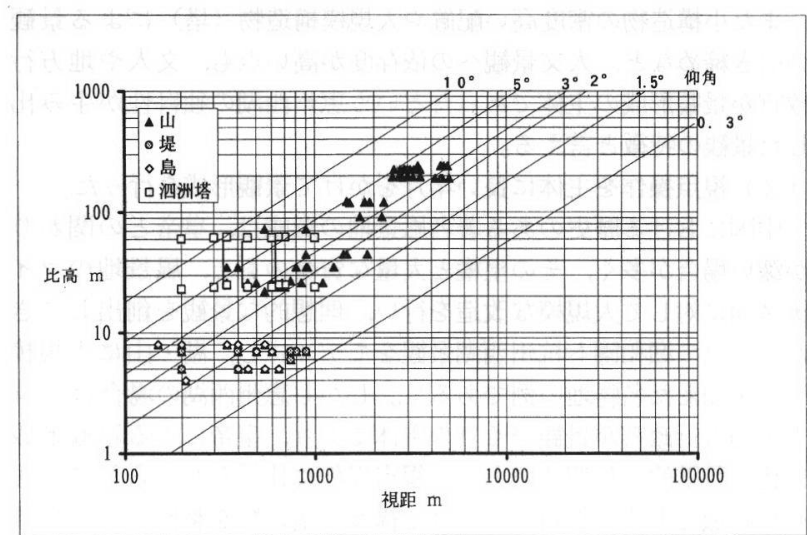

図ー13 恵州西湖における泗洲塔と視対象の見え方（宋時代）

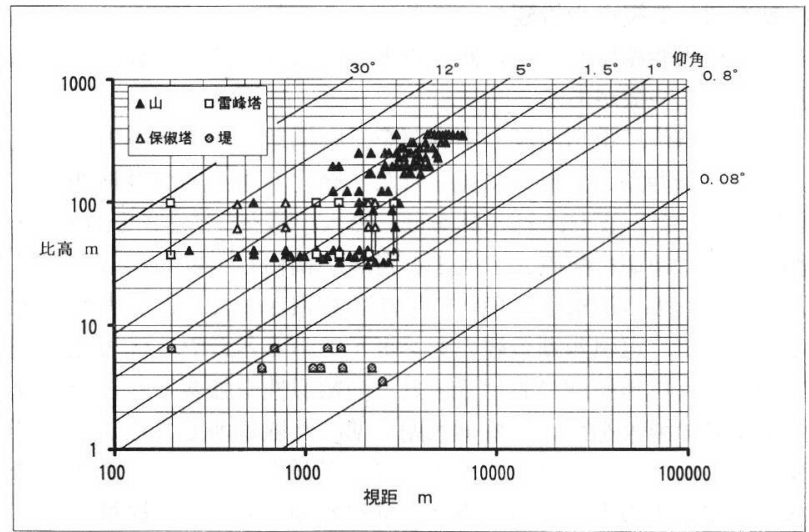

図－14 杭州西湖における塔と視対象の見え方（宋時代）

代表景となっている。図一 7 によると，蘇氏以降，泗洲塔以外に， 北部菱湖湖畔の万寿山低山山頂の「万寿塔」や，大河の畔に位置 した「文星塔」（民国時期崩れた）が整備された。これらの構造 物が分節された湖の各区域において，景観上の注視点となり，景 観にまとまりを与えていた。これらの景観については十分な記録 が残されておらず，杭州西湖の景観との直接の関連性を知ること ができないが，重要な構造物の配置を通じて，景観にメリハリを 与え, 自然山水のポテンシャルを引き出すといった同じ手法が用

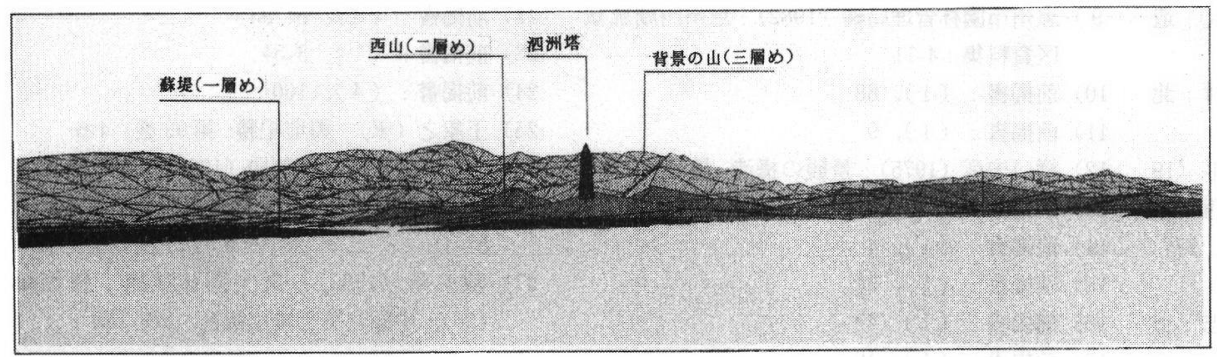

図-15 恵州西湖の明月湾から「玉塔微瀾」を望むパース $(50 \mathrm{~m} \mathrm{MESH})$

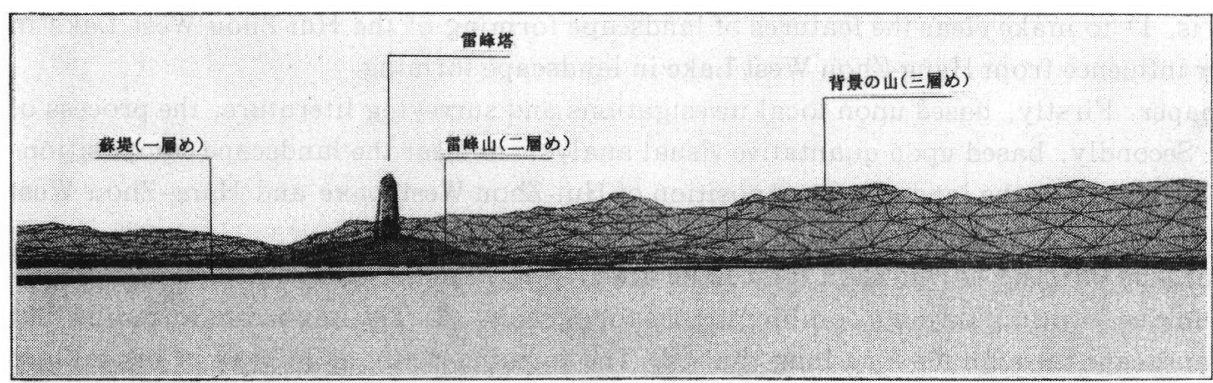

図ー16 杭州西湖の丁家山から「雷峰夕照」を望むパース (50m MESH)
いられていた点は指摘できる。

一方, 小構造物に関しては, 湖畔の初めての拠点である「興 龍寺」が建てられたのが 4 世紀である。それ以降, 寺, 庭園, 書 院, 小橋, 四阿などの整備が徐々に進められ, 市街地之山の間に 位置する湖上, 湖畔に隣接している山上にも散在するようになっ た。こうした構造物の配置も, 杭州西湖に類似しており, 都市か ら湖をへて，山につながる景観がスムーズに連続するように，人 文要素之自然要素の巧みな融合が行われていたことが指摘できる。 上述した視覚分析の結果から，以下の点が考察される。

景観成立期に蘇氏が主導した島堤の整備は, 景観上の分節感を 与えた上に, 湖面に第一層を加えることによって, 水景演出に効 果を与え, 全体の景観に奥行感を与える役割を果たした。また, 蘇氏が選出した視点からの景観は, 地形上の制約から層状が明確 でない恵州西湖景観の中でより三層構造が明瞭なものが抽出され ている。さらに大規模構造物である塔は, 景観に注視点を与える 之同時に，杭州西湖景観之類似性を強調するあのである。また， 各時代の構造物の整備（社寺, 庭園・橋などの整備）によって自 然と人文との融合景観が形成され, 徐々に理想の「境」へ近づけ ようとする動きとなっていた点む指摘できる。

(iii) 名景づくり

中国における歴史的な自然風景地は, 地域の特徴を象徴する名 景を有しており, 恵州西湖にも「恵州八景」や「十四景」が存在 している。しかしながらこれらの名景は同一レベルに並んでいる あのではなく, 歴史の中で度々強調された中心となる代表景が存 在した (恵州西湖は「玉塔微瀾」と いう景観である)。

そして同時に蘇東坡ら文人による 詩文や書画での活動を通して, 特定 の視点からの優れた景観を世に広め, 恵州西湖を象徴する景観として定着 させるという作業も行われた。この 視点の整備とそこからの景観の著名 化という形で進められる「名景づく り」は, 蘇氏によって名景（視点） が選ばれ詠われて以来, 数多く繰り 返されてきた。定着した恵州西湖の 名景の中には, 杭州西湖の名景との 類似性を指摘されているものがあ $3^{23)}$ 表 -1 が示す 6 景である。これ らの「名景」について, DTM を屯 とに作成した透視図による類似性の 検討を行った。図一-15，16 に示す のはその 6 景の一組の「玉塔微闌 (雁塔斜暉)」と「雷峰夕照」景観の パースである。画中にある堤, 湖畔 
表一 1 杭州西湖名景に対応した恵州西湖の景観

\begin{tabular}{|c|c|}
\hline 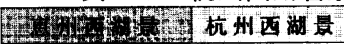 & Wf. \\
\hline (1)点翠洲 - - - - 三潭印月 & (4)曲院風荷…- - 曲院風荷 \\
\hline (2)煙震堤………白堤 & (5) 玉塔微瀾 - - - - - 雷峰夕照 \\
\hline (3) 弧山 $\cdots \cdots$ & (6) 蘇堤玩月 \\
\hline
\end{tabular}

の低山, 背景となった遠視距の高山, そして配置された構造物な どによって形成される景観には杭州西湖景観との類似性が読みと れる。これらの 6 景は, 杭州西湖により近い洗練された景観が選 ばれていると言えよう。

以上のように，文人などによる文化的活動を通して「名景化」 を行い，より洗練された景観によって恵州西湖全体の景観を代表 させて, 恵州西湖を印象づける手法の活用は, 恵州西湖の特徵之 あ言うべきものであろう。そして,一つの景観を名景として定着 させていく過程において，既に評価を得ていた杭州西湖の名景と の類似性の強調が重要な役割を果たしたと言える。

\section{4.まとめ}

前述の分析結果をまとめると, 恵州西湖の景観形成の特徴とし て下記の点があげられる :

（1）杭州西湖景観の影響を受けつつも，立地条件に合わせた独 自の景観形成を行った。

恵州西湖の景観は大スケールでの立地条件や空間構成において 杭州西湖と似ていること，そして景観形成の契機を与えた蘇東坡 が杭州西湖の景観形成にも大きな影響を及ぼした人物であったこ と，また，杭州西湖が同条件の景観モデルとして先駆的に高い評 価を得ていたことから，杭州西湖と潜在的に深く関連し，その影 響の下に景観形成が展開した。しかし，土地の条件を十分に活用 して特徴ある景観を創出することが風景地における景観づくりの 共通の課題である。恵州西湖は歴代の文人などによる整備の結果, 狭長で曲折した湖の形状と, 周辺の山の平・立面ともに変化の多 い地形が活かされ, 空間分節によって奥行感を増加させっつも, こじんまりとまとまりが感じられる独自の景観が形成された。
また小構造物の密度高い配置や大規模構造物（塔）による景観 の引き締めなど, 人文景観への依存度が高い点も, 文人や地方行 政官が景観形成の主体であったという恵州西湖の独自性が生み出 した景観の特徴と言える。

（2）視点操作を主体に長い年月をかけて景観形成を行った。 中国における歴史のある著名風景地の形成は, 皇帝との関わり が深い場合が多く, その皇権と大量な資金のもと, 風景地のマイ ナス面に対して大規模な改造を行い，理想的な景観を創出してき た。北京の頋和園も杭州西湖景観をモデルにし, 湖・山に大規模 改造を加えた名勝地の例である4)。しかし恵州西湖の場合は，文 人・地方行政官が景観づくりの主体であり，皇帝による景観形成 に比へ段階的, 長期的であり, 視点操作に比重がかけられている 点が特徴である。数百年をかけて徐々に構造物を整備しつつ湖周 辺に適切に配置し，さらに詩文・絵画で恵州西湖景観を潤色する 活動を通して視点や景観を定着させていった。

（3）杭州西湖における景観形成手法に類似しているものの, 名 景化手法に特徵がある。

蘇氏の時代, 恵州西湖の中央部を三層構造に近づける工夫が見 られ，杭州西湖景観形成に見られた「首化」手法 ${ }^{24)}$ が恵州西湖て あ展開された。また, 社寺林をはじめ大小様々な構造物を山・湖・ 都市の間に適切に配置し，人工と自然か調和した景観形成を図る ことで, 仙境の追求や「境化」手法が意識されたことが考察され る。そして, 恵州西湖景観のシンボルである名景や, 代表景の創 出の際に, 杭州西湖における名景との類似性を強調した視点の選 定や景名の導入を行い，杭州西湖に準じた風景地であることの印 象づけを圀っていった。このような「名景化」，つまり都市に隣 接した風景地の人工改造を避け，杭州西湖の名景との提携によっ て恵州西湖景観の質的な昇華を図った点は，恵州西湖における文 人が主体の景観形成の重要な特徽と指摘できる。

以上, 層化や境化など杭州西湖の景観形成手法との類似性が見 られるが, 名景化手法に恵州西湖における景観形成の特徴があり, 景観形成の主体が文人であったことの影響を見ることができる。

\section{参考引用文献}

1 ) 張友仁 (1989)：恵州西湖誌: 広東省高等教 育出版社 (複刻版), 322

2) 沈悦・熊谷洋一・下村彰男 (1995)：中国西 湖の景観構成之その形成に関する研究 : 造 園雑誌 58(5)，156-160

3) 林福昌 (1993)：西湖景観芸術美的探討：北 京園林 25(3)，10-15

4) 沈悦・熊谷洋一. - 下村彰男 - 小野良平（19 97）: 北京頣和園における景観形成と西湖景 観の影響について：造園雑誌 60(5)，577582

5 ）天一閣蔵明代地方志 (明)：正徳穎州志：上 海古籍書店, 3

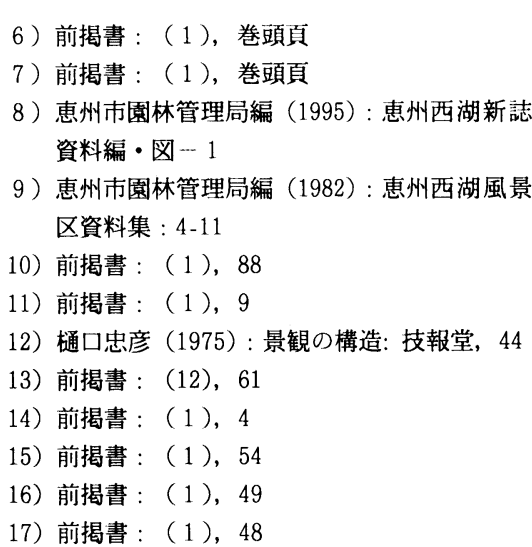

18）前掲書：（1）, 85

19) 前掲書 : (1), 10-12

20）前掲書：（8）, 84-114

21）前掲書 : (1 ), 215-261

22）前掲書：（8）, 81-83

23）前掲書 : (1), 3-54

24）前掲書 : (4), 160

25）王象之（宋）：興地紀勝：第 99 巻，4-6

26）広東省恵州園林管理局（1982）：恵州西湖園 林風景区的形成和特点：広東園林（13）, $37-41$

27）陳志華（1989）：文士園林試論：建築師 （36），中国建築丁業出版社，179-188

Summary: The aim of this study is, 1) to make clear the features of landscape forming of the Hui-Zhou West Lake in Guang Dong and 2) to make clear influence from Hang-Zhou West Lake in landscape forming.

Two methods are applied in this paper. Firstly, based upon local investgations and surveying literature, the process of landscape forming is made clear. Secondly, based upon quantative visual analysis to clear the landscape composition, the characteristic is found through comparing the landscape composition of Hui-Zhou West Lake and Hang-Zhou West Lake.

In conclusion, the features of landscape forming of Hui-Zhou West Lake are 1) it is ifluenseced by landscape of HangZhou West Lake, but it showed a unique formimg through combinning the topography. 2) The important formul is that make good points of view to see landscape through the long long time. 3) The forming methods appear in resemblace between Hui-Zhou West Lake and Hang-Zhou West Lake, and the "creating typical landscape" is main feature. 